\title{
A ESTÉTICA DO CONSUMO NA INTERTEXTUALIDADE ENTRE CINEMA E PUBLICIDADE FÍLMICA
}

Marcelo Eduardo Ribaric ${ }^{1}$

\section{Resumo}

Este ensaio analisa um efeito particular na relação dialógica entre o cinema e a publicidade audiovisual, o da estética do consumo, cuja presença se dá como representação da sociedade contemporânea, onde a publicidade não cria nem desencadeia novos hábitos de consumo, apenas refletindo e refratando aqueles hábitos culturais já consagrados nestas sociedades, pois ela nada mais é do que uma simples expressão destas culturas. Este efeito particular da narrativa do filme publicitário endereça as suas mensagens, impregnando a sociedade de uma ordem simbólica e de um poder sedutor construído pelas propriedades da imagem audiovisual; por sua sensibilidade, que lhe permite invadir a qualquer momento o espaço individual para constituir imagens intensamente convincentes e, sobretudo, por sua inquietante capacidade de "olhar nos olhos" de sua audiência, quer seja pela televisão, cinema, internet ou mesmo pelo telefone celular, nenhuma das representações do filme publicitário escapa ao caráter sugestivo próprio da publicidade. Sua imagem em alta definição não visa a nitidez, mas sim, o relevo, a projeção de uma terceira dimensão, a da mensagem publicitária que procura conseguir, através dos olhares de seus espectadores, o seu sentido social. Por fim, o problema a ser investigado por esta pesquisa é justamente saber como se dá a construção narrativa da publicidade contemporânea, base da interação associativa de conteúdos com os produtos publicizados, buscando impor determinada imagem/signo que não se refere diretamente nem ao produto que anuncia, nem à realidade concreta de que se origina, mas sim, a um sistema de valores vigentes na sociedade a que se dirige a mensagem, reestetizando os signos e seus significados.

Palavras-chave: publicidade fílmica; cultura; intertextualidade; consumo; cinema.

\footnotetext{
${ }^{1}$ Professor da Universidade Tuiuti do Paraná, doutorando em Comunicação e Linguagens pela UTP. Email mribaric@gmail.com
} 


\begin{abstract}
This essay examines a particular effect on the dialogic relationship between cinema and audiovisual advertising, the aesthetics of consumption, whose presence is given as a representation of contemporary society, where advertising does not create or triggers new consumption habits, just reflecting and refracting cultural habits of those already established in these societies because it is nothing more than a simple expression of these cultures. This particular effect of the film's narrative addresses their advertising messages, permeating society from a symbolic order, a property built by the seductive power of the visual image, for its sensitivity, which allows you to invade personal space at any moment to form intensely convincing images, and especially for its unsettling ability to "look into the eyes" of its audience, whether by television, cinema, internet or by mobile phone, none of the representations of the advertising film escapes the suggestiveness of its own advertising. Its high definition picture does not intend to achieve sharpness, but relief, the projection of a third dimension to the advertisement that seeks to achieve, through the eyes of its viewers, its social meaning. Finally, the problem to be investigated by this research is to know precisely how the narrative construction of contemporary advertising, associative basis of the interaction with the content with publicized products, seeking to impose certain image / sign that does not refer directly to the product or advertising, nor the reality that it stems from, but rather a system of values prevailing in society for whom the message, reaestheticize the signs and their meanings.
\end{abstract}

Keywords: film advertising; culture; intertextuality; consumption; cinema. 


\section{Introdução}

A publicidade audiovisual contemporânea, seja no formato tradicional de spot de 15 , 30 ou 60 segundos, seja em uma inserção em outras narrativas como no chamado merchandising, em filmes, novelas ou programas televisivos ou mesmo no advertainment, faz uso da linguagem cinematográfica que, ao exercer seu papel de ampliar o universo em que os bens culturais ganham sentido, não se restringe somente a apontar características objetivas de um produto, ele é inserido em redes de significações, contextualizado em práticas sócioculturais. A linguagem publicitária compõe midiapanoramas (APPADURAI, 1999, p.315316) nos quais a mercadoria reorganiza os elementos do mundo em função de sua própria lógica. Vindo as mercadorias a atender a "necessidades" e "desejos", conforme os princípios do marketing, introduzindo-se em processos nos quais o reconhecimento de valores, utilidades, estímulos estabelece um consumo simbólico. desta forma são transmitidos planos para o entendimento do próprio mundo. A partir da linguagem, mundos admissíveis são construídos em torno de objetos que sustentam o imaginário contemporâneo e seus cenários culturais. De acordo com Rossi-Landi

Como os outros produtos do trabalho humano, as palavras, expressões e mensagens têm um valor de uso ou utilidade na medida em que satisfazem necessidades; no caso, as necessidades fundamentais de expressão e de comunicação com todas as mutáveis estratificações que se acumularam historicamente e se emaranharam em volta delas. Sem signos linguísticos, é impossível satisfazer essas necessidades em nível humano. Uma vez aceita a concepção da linguagem como trabalho, a primeira hipótese de indagação que se apresenta é que também as palavras e as expressões venham a ser empregadas, e as mensagens transmitidas e recebidas, não apenas segundo seu valor de uso, mas também, e principalmente, segundo seu valor de troca (ROSSILANDI, 1985, p.86).

\section{A linguagem e o cinema}

"Nenhuma outra invenção foi capaz de abreviar distâncias, como o cinema. Distâncias entre as décadas, entre os países, entre as culturas 


\section{e, acima de tudo, entre a imaginação e a realidade". (Luís Buñuel)}

Nos estudos contemporâneos a linguagem é vista como um sistema flexível da cultura de determinadas sociedades humanas. Castells (1999) e Martín-Barbero (2003) reconhecem como elementos centrais que influenciam na formação de práticas culturais, a compreensão da cultura como resultado da comunicação mediada pelas interações com as diferentes linguagens - expressão de sistemas de códigos produzidos pela humanidade - e o desenvolvimento das tecnologias de informação e comunicação.

De acordo com a teoria de Rossi-Landi, a produção de linguagem é o resultado do trabalho humano, pois a linguagem é desenvolvida em função da imagem que se faz do interlocutor, de suas expectativas, de suas deficiências. Produzida para ser um processo interacional, visando ser assimilada, ou seja, consumida. Especificamente quando tratamos da comunicação mercadológica, as estratégias de persuasão têm como ponto de partida o cálculo enunciativo que modula a linguagem em função da proposta de incorporação de valores e convite à ação. Lança produtos, serviços, organizações no plano da economia, de acordo com Bourdieu, de trocas simbólicas juntamente com ideias e valores. O consumo da comunicação se realiza na forma como o interlocutor a recebe. A partir da obra de Mikail Bakhtin, Marxismo e filosofia da linguagem, compreendemos toda comunicação como sendo dialógica; que se identifica na emissão como proposta de consumo, como sugestão de mundos possíveis em torno das mercadorias no mundo da publicidade.

Este posicionamento se reforça quando a questão da linguagem é relacionada ao ato de narrar, e no caso deste estudo, narrar através de um filme. A narrativa faz com que as pessoas se identifiquem e se percebam como parte de uma sociedade no fenômeno da linguagem, como também parte das ações que possibilitam descrever, imaginar ou relatar uma história.

A linguagem cinematográfica é um fenômeno que se manifesta na manipulação da imagem em movimento, com a intenção de estabelecer um diálogo com o espectador.

Segundo Christian Metz, os filmes narrativos e documentários têm sido considerados como discursos e devem ser tratados como textos, unidades de discurso ou, em suas próprias palavras, "o filme enquanto discurso significante (texto)" (Metz, 1980 p. 12). Jacques Aumont é mais preciso a esse respeito, afirmando que: 


\begin{abstract}
A narrativa fílmica é um enunciado que se apresenta como discurso, pois implica, ao mesmo tempo, um enunciado (ou pelo menos um foco de enunciação) e um leitor-espectador. Seus elementos estão, portanto, organizados e colocados em ordem de acordo com muitas exigências: em primeiro lugar, a simples legibilidade do filme exige uma "gramática" (trata-se aí de uma metáfora), a fim de que o espectador possa compreender, simultaneamente, a ordem da narrativa e a ordem da história (Aumont, 1995, p. 106)
\end{abstract}

Ele conclui dizendo: "Essa organização deve estabelecer o primeiro nível de leitura do filme, sua denotação; [...] em seguida, deve ser estabelecida uma coerência interna do conjunto da narrativa. [...] finalmente, a ordem da narrativa e seu ritmo são estabelecidos em função de um encaminhamento de leitura que é, assim, imposto ao espectador. É, portanto, concebido também em vista de efeitos narrativos. [...] é um discurso fechado, porque comporta inevitavelmente um início e um fim, porque é materialmente limitado" (Ibid, pp. 106-108).

Já os primeiros estudos do cinema com Leon Kuleshov, professor e teórico da primeira escola de cinema, no final da década de 1910, na União Soviética, tinham especial interesse na construção da linguagem cinematográfica e na formulação de sua estrutura, a fim de identificar os efeitos que as obras poderiam causar sobre o público e, principalmente, que elementos contidos na obra resultariam em reações mais favoráveis por parte dos espectadores e qual seria sua estrutura.

A pluralidade de linguagens com que o cinema trabalha, contribuiu para desenvolver inúmeras teorias sobre a construção da sua própria linguagem. Esse aspecto traz à tona alguns problemas, sobretudo os do campo da enunciação. O texto fílmico revela vestígios das diferentes linguagens que lhe deram origem.

A linguagem cinematográfica possui a referência de outras linguagens, como comenta McLuhan, para quem o cinema,

... sendo uma forma de expressão não-verbal, como a fotografia, é uma forma de expressão sem sintaxe. No entanto, como a impressão e a fotografia, o cinema pressupõe um alto índice de cultura escrita em seus apreciadores, ao mesmo tempo em que intriga os analfabetos ou não-letrados (MCLUHAN, 1979, p.320). 
O cinema trabalha sua linguagem de tal maneira que leva o espectador a consumir um produto intangível, carregado de significados e valores simbólicos, transformados em bens de consumo pela indústria cultural e pelo capitalismo. Na visão de McLuhan, "não é por acaso que o cinema se caracterizou como o meio que oferece, aos pobres, papéis de riqueza e poder que superam os sonhos da avareza" (1979, p.327). Assim, padrões de comportamento, valores morais, hábitos culturais e de consumo, juntamente com produtos, são oferecidos ao espectador através da obra cinematográfica.

Segundo Walter Benjamin, em seu artigo "A obra de arte na era de sua reprodutibilidade técnica" (in Obras escolhidas, volume 01, 1993):

... o filme serve para exercitar o homem nas novas percepções e reações exigidas por um aparelho técnico cujo papel cresce cada vez mais em sua vida cotidiana. Fazer do gigantesco aparelho técnico do nosso tempo o objeto das inervações humanas, é essa a tarefa histórica cuja realização dá ao cinema o seu verdadeiro sentido (BENJAMIN, 1993, p.174).

Quando pensamos no caso dos filmes de advertainment, é impossível não nos atermos às novas percepções e reações, promovidas pelo uso do computador e da internet, bem como as tecnologias desenvolvidas para transmiti-los para os usuários, uma vez que se tratam dos primeiros filmes produzidos pensando no meio "computador", na sua transmissão e na adequação das linguagens cinematográficas e televisivas.

\section{A materialização da linguagem cinematográfica}

A sensação de estar diante de uma janela e testemunhar a ação reforçam a impressão de realidade que caracteriza os filmes. Além do fenômeno da impressão de realidade, já percebido e relatado por Hugo Münsterberg no seu "The photoplay: a psychological study", em 1916, que interpunha à "naturalidade" das imagens, a atenção e o processo mental do espectador, ativado por outros elementos da linguagem cinematográfica, como o corte e a escala, o que realmente importa é a psicologia da forma, isto é, o ponto de partida na operação do aparato cinema seria o elemento externo, o restante do processo se completaria na mente do espectador. 
Para Walter Benjamin, "a história é objeto de uma construção cujo lugar não é o tempo homogêneo e vazio, mas um tempo saturado de agoras" (1993, p. 229).

\section{Relações intertextuais entre o cinema e a publicidade audiovisual}

O diálogo entre o cinema e a publicidade audiovisual remonta às origens do próprio cinema. O primeiro filme publicitário de que se tem notícia foi produzido por Thomas Edison e data de 5 de agosto 1897, pouco mais de um ano após a primeira exibição do cinematógrafo dos irmãos Lumiére, em dezembro de 1895.

Era de um comercial dos cigarros "Admiral" (figura 1), que utilizava a linguagem cinematográfica da época, uma estética de "teatro filmado".

Com a câmera parada, sem som, sem cortes ou montagem, a ação se resumia a um grupo de homens sentados juntos, cada um vestido representando um grupo social distinto, mostrando-se entediados, ao lado de uma grande embalagem de cigarros "Admiral" e, atrás delas, o logotipo do produto. De repente, a grande embalagem se abre e surge um homem fantasiado do que deveria ser um almirante, que sai distribuindo cigarros para aquelas pessoas que estavam sentadas, que abrem uma faixa com os seguintes dizeres: "We all Smoke", e apontam para o logotipo acima de suas cabeças enquanto cai uma "chuva" de cigarros.

Essa teatralização da narrativa era uma referência direta às pequenas comédias do vaudeville, tão comuns na época.

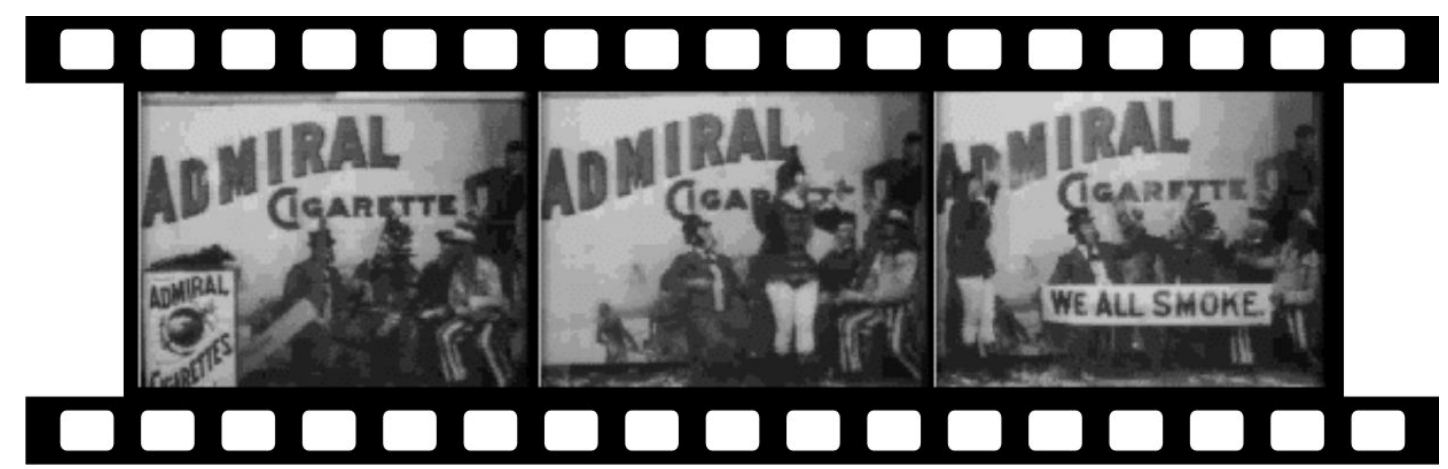

Figura 1 - Primeiro comercial cinematográfico.

Essa "estética de teatro filmado" surge com o francês Georges Méliès, criador do 
espetáculo cinematográfico, o primeiro a encaminhar o novo invento no rumo da fantasia, transformando a fotografia animada em meio de expressão artística, valendo-se para isso de cenários e efeitos especiais em todos seus filmes, até em cinejornais, que reconstituíam eventos importantes, com maquetes e truques ópticos.

Méliès, em 1897, começa a construir uma linguagem cinematográfica ao descobrir a trucagem no cinema e perceber seu potencial criativo, bem como ao utilizar o recurso da exposição múltipla de negativos, da fotografia composta, de todos os expedientes oferecidos pelo teatro, do processo de pintura sobre película, para se conseguir "filmes coloridos", entre outras coisas.

O cinema e a publicidade fílmica, que surgiram no mesmo momento, passam a dialogar rapidamente entre si. Graças a um caráter mimético, a publicidade imita, homenageia, parodia, sintetiza diversas linguagens. Esta incursão de linguagens no discurso publicitário como intertexto, explica seu frequente recurso a alguns dos modelos discursivos mais reconhecíveis - a fala diária, o jornalístico, o literário e o cinematográfico, sem esquecer-se do fato que, em muitas ocasiões, a incursão é feita com mais de um desses discursos.

Este caráter da linguagem publicitária já tem sido evidenciado, seja do ponto de vista linguístico ou a partir de perspectivas da análise pragmática ou da análise do discurso, que a integram à imagem, à música, etc, como afirma Goiamérico Felício C. dos Santos (2006, p.69) "Esse caráter mimético, protéico, proteiforme, mutante, dessa linguagem da sedução ao longo do tempo vem impondo-se em todos os lugares e situações de nossas vidas, principalmente a partir da era da modernidade tão amplamente midiatizada", característica também reafirmada por Beatriz Sarlo (2004) e Ignácio Ramonet (2002).

O discurso publicitário se expressa de formas muito distintas: do anúncio mais simples nos panfletos de ofertas de supermercados ao mais criativo e premiado. O que essas peças possuem em comum é a finalidade persuasiva e mercantil, que as torna parte do mesmo gênero.

Essa relação dialógica faz parte do fenômeno da polifonia, questão levantada por Mikail Bakhtin no seu trabalho sobre a "Filosofia da Linguagem", e leva a ponderações sobre outro elemento da análise do discurso, a heterogeneidade, que se apresenta sob as formas de 
heterogeneidade constitutiva, caracterizada pelo interdiscurso, e heterogeneidade mostrada, baseada na intertextualidade.

Segundo Bakhtin, "tudo se reduz ao diálogo, à contraposição enquanto centro. Tudo é meio, o diálogo é o fim. Uma só voz nada determina nada resolve. Duas vozes são o mínimo de vida." (2005, p. 257). A idéia central das relações denominadas convencionalmente por intertextuais surgiu em no começo do século XX, como um meio para estudar e reconhecer o intercâmbio existente entre autores e obras, configurando-as como dialogismos.

Todas as palavras e formas que povoam a linguagem são vozes sociais e históricas, que lhe dão determinadas significações concretas e que se organizam no romance em um sistema estilístico harmonioso [...] (BAKHTIN, 1988, p.100).

A noção de recepção/compreensão proposta por Bakhtin ilustra o movimento dialógico da enunciação, a qual constitui o território comum do locutor e do interlocutor. Diálogos também conhecidos por outros termos, como intertextualidade, enquanto as relações entre vários discursos estudadas no decorrer do século XX se mantiveram como tema e procedimento importantes na interpretação da cultura.

O termo intertextualidade foi criado por Julia Kristeva a partir da leitura da obra de Mikhail Bakhtin. Filmes que retomam filmes, quadros que dialogam com livros, propagandas que se utilizam do discurso de outros, tudo isso são textos em diálogo com outros textos, ou seja, intertextualidade. É dela o clássico conceito de intertextualidade: “(...) todo texto se constrói como mosaico de citações, todo texto é absorção e transformação de um outro texto." (KRISTEVA, 1974, p. 64).

Em sua essência, a idéia bakhtiniana de heteroglossia, o diálogo que existe em todo texto com textos diferentes, está na base de qualquer definição da intertextualidade. É a afirmação de que cada texto é, na verdade, um mosaico de citações, no qual a absorção e a transformação dos textos lidos anteriormente pelo escritor nos incitam a desvelar o que está oculto com maior ou menor intenção.

A intertextualidade pode ser definida então como uma característica do discurso, este entendido como unidade comunicativa, que consiste em uma relação de dependência com outros discursos ou classes de discurso, em um jogo intencional entre o emissor e os 
destinatários de uma mensagem que contribuem ao discurso. Esta intencionalidade se dá por meio da inferência e da dedução de conteúdos implícitos - uma leitura adicional que soma à informação proporcional. Pode ser uma citação literal, uma insinuação a uma convenção social, uma homenagem a um filme ou a um gênero fílmico, o uso oculto ou expresso de outros tipos de discurso, em resumo, uma piscadela que o emissor dirige ao receptor.

O conceito de intertextualidade como a relação de dependência de todo discurso com outros discursos ou gêneros discursivos, se apresenta como um das principais características da publicidade, como linguagem complexa em que se põem em jogo qualquer meio de expressão existente.

De acordo com Carrascoza (2008), a criação publicitária é um processo de associação de idéias, uma associação de diversos discursos.

\begin{abstract}
Não é por acaso que a associação de idéias, e, sobretudo a livre associação, juntamente com a interpretação dos sonhos, constitui uma das pedras fundamentais do método freudiano. Tampouco que a publicidade seja resultante de uma bricolagem, da edição de partes de vários discursos; e editar, sabemos, é uma forma de unir, atar, associar (CARRASCOZA, 2008, p.16).
\end{abstract}

Carrascoza prossegue dizendo que os criativos das agências de propaganda, duplas formadas por redatores e diretores de arte, são vistos como os bricoleurs, cuja "missão é compor mensagens, preferencialmente de impacto, valendo-se dos mais diversos discursos que possam servir ao propósito de persuadir o público-alvo" (2008 p.18). Movidos por um sistema de trabalho full-time que os obriga a produzir idéias originais e eficazes em prazos cada vez menores, os criativos lançam mão de referências e associações de idéias. Muitas vezes chegando aos mesmos resultados, o que leva a obra ao campo da autoria das idéias.

Ainda segundo o autor:

Num anúncio que incorpora um ready-made, a dupla de Criação faz uso, no processo associativo, daquilo que Maingueneau denominou de "enunciados fundadores", pois já são tesouro da coletividade, gozando do privilégio da intangibilidade. Isso porque esses enunciados "não podem ser resumidos nem reformulados, constituem a própria Palavra, captadas em sua fonte. (CARRASCOZA, 2008, p.79) 
No caso da publicidade audiovisual, os profissionais de agências se valem do material cultural das obras fílmicas (cinematográficas ou televisivas) no seu processo de criação, dialogando de forma direta ou indireta com elas.

Ainda segundo o autor, na bricolagem publicitária é essencial que o profissional possua um vasto conhecimento cultural, pois é a partir deste conhecimento que ele terá a capacidade de extrair signos que mais se adequam à solução de comunicação desejada.

Além desta capacidade de identificar os signos mais adequados, exige-se também, destes profissionais, que eles "aperfeiçoem a habilidade de combinar os variados discursos por meio do jogo intertextual." (CARRASCOZA, p.71), Visando facilitar a adesão de um público específico, o qual se deseja atingir através da mensagem publicitária, é comum a utilização de signos pertinentes ao universo do mesmo no processo de bricolagem.

"Esses materiais culturais, populares ou eruditos, são utilizados como pontos de partida para a criação das peças de propaganda, aparecendo sob forma de citação direta ou indireta, o que nos leva ao conceito de dialogismo de Bakhtin. Ou seja: um texto sempre dialoga com outros, sendo esse o princípio constitutivo da linguagem." (CARRASCOZA, p.71)

Desta forma, todo texto é construído a partir de fragmentos de outros textos por meio da citação, da alusão ou da estilização, independentemente da consciência ou não de seu enunciador.

O discurso publicitário é eficaz na medida em que assume a linguagem da atividade, do universo ideológico do consumidor; de sua tradição cultural. Quando, por exemplo, um spot é feito para atingir o público jovem, é preciso que ele faça uso do repertório cultural deste público. Um aparelho celular com funções para ouvir música precisa entrar no universo dos hábitos de consumo de música dos jovens.

Segundo Deleuze:

A partir, sobretudo da Segunda Guerra Mundial, os clichês começaram a aparecer naquilo que são - meros clichês: os clichês da relação, os clichês do amor, os clichês do povo, os clichês da política ou da revolução, os clichês daquilo que nos liga ao mundo - e é quando eles assim, esvaziados de sua pregnância, se revelaram como clichês, isto é, imagens prontas, pré- fabricadas, esquemas reconhecíveis, meros decalques do empírico, somente então pôde o pensamento liberar-se deles e abrir-se 
para outras dimensões do comum (DELEUZE, 1999).

Assim, a publicidade audiovisual recorre a apelos verbais ou visuais que objetivam a fazer acreditar naquilo que se propõe, através de idéia básica ou de um tema. Esses apelos podem vir concretizados em imagens através da linguagem cinematográfica.

Podemos citar como exemplo da relação intertextual através da paródia, o filme publicitário da agência de publicidade americana BBDO New York, criado para empresa Fedex, logo após o lançamento do filme "O Náufrago". O filme original terminava com o personagem "Chuck" entregando a última encomenda que lhe havia restado e por ele mantida fechada, depois de passar anos de privação em uma ilha deserta.

Na paródia publicitária (figura 2), alguém que lembra o personagem "Chuck" vai entregar uma encomenda e diz para a mulher a quem entrega: “- Olá, eu fiquei perdido numa ilha durante oito anos com este pacote, e eu jurei que o entregaria a você, porque eu trabalho para a Fedex." Antes de ir embora, curioso, ele pergunta à mulher o que há no pacote, ao que ela responde: “- Nada de importante, apenas algumas besteiras ..., um celular por satélite, um localizador GPS, uma vara de pesca, um purificador de água e algumas sementes ...”, ou seja, tudo aquilo que seria útil para sua sobrevivência e resgate na ilha deserta.
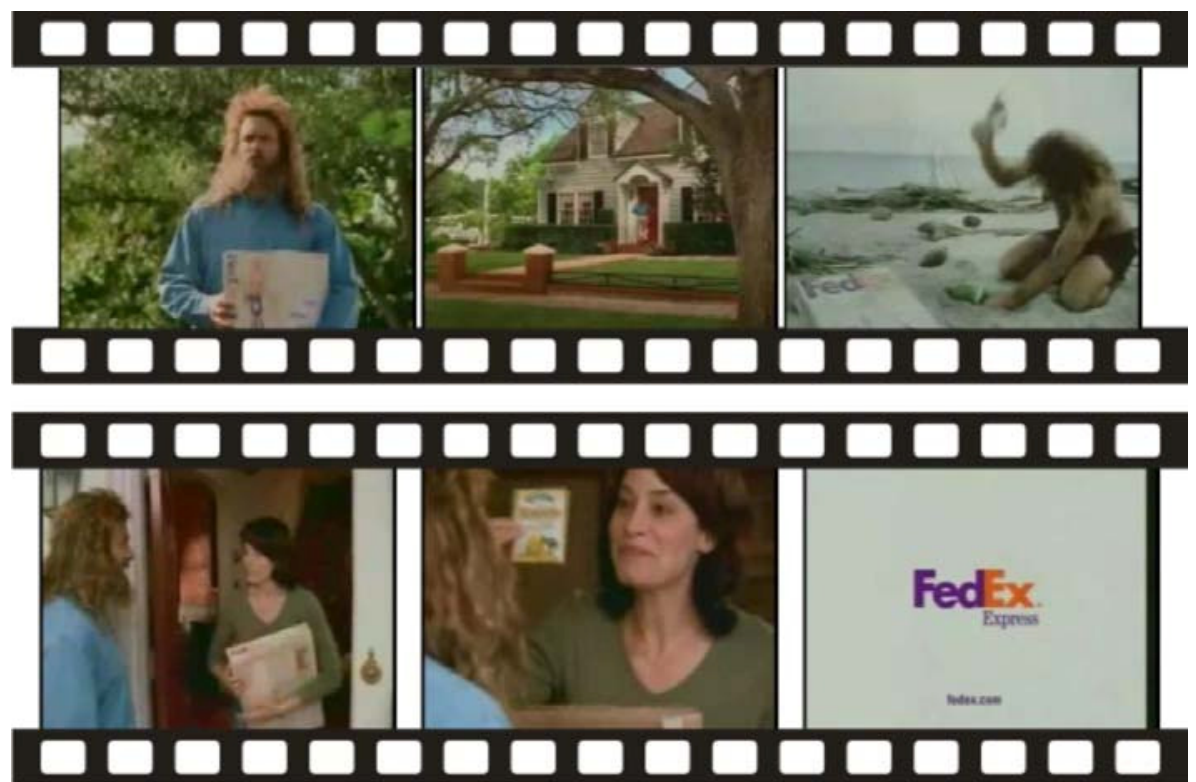

Figura 2 - Spot para a empresa Fedex, paródia do filme "O náufrago".

Como exemplo da paráfrase, podemos mencionar o spot criado pela agência 
brasileira AlmapBBDO (figura 3), em 2007, para o novo modelo de automóvel "Golf", da marca Volkswagen, em uma citação ao filme "Forrest Gump, o Contador de Histórias", de 1994, também estrelando Tom Hanks, brincando com a cena em que o personagem "Forrest Gump" corre a pé por horas, dias e anos sem parar (mais precisamente 3 anos, 2 meses, 14 dias e 16 horas).

A diferença é que na campanha publicitária, ele faz sua longa viagem dirigindo um automóvel Golf e, Assim como no filme "Forrest Gump", no comercial, o personagem é aclamado pelo público como um herói, ganhando diversos seguidores durante sua jornada.

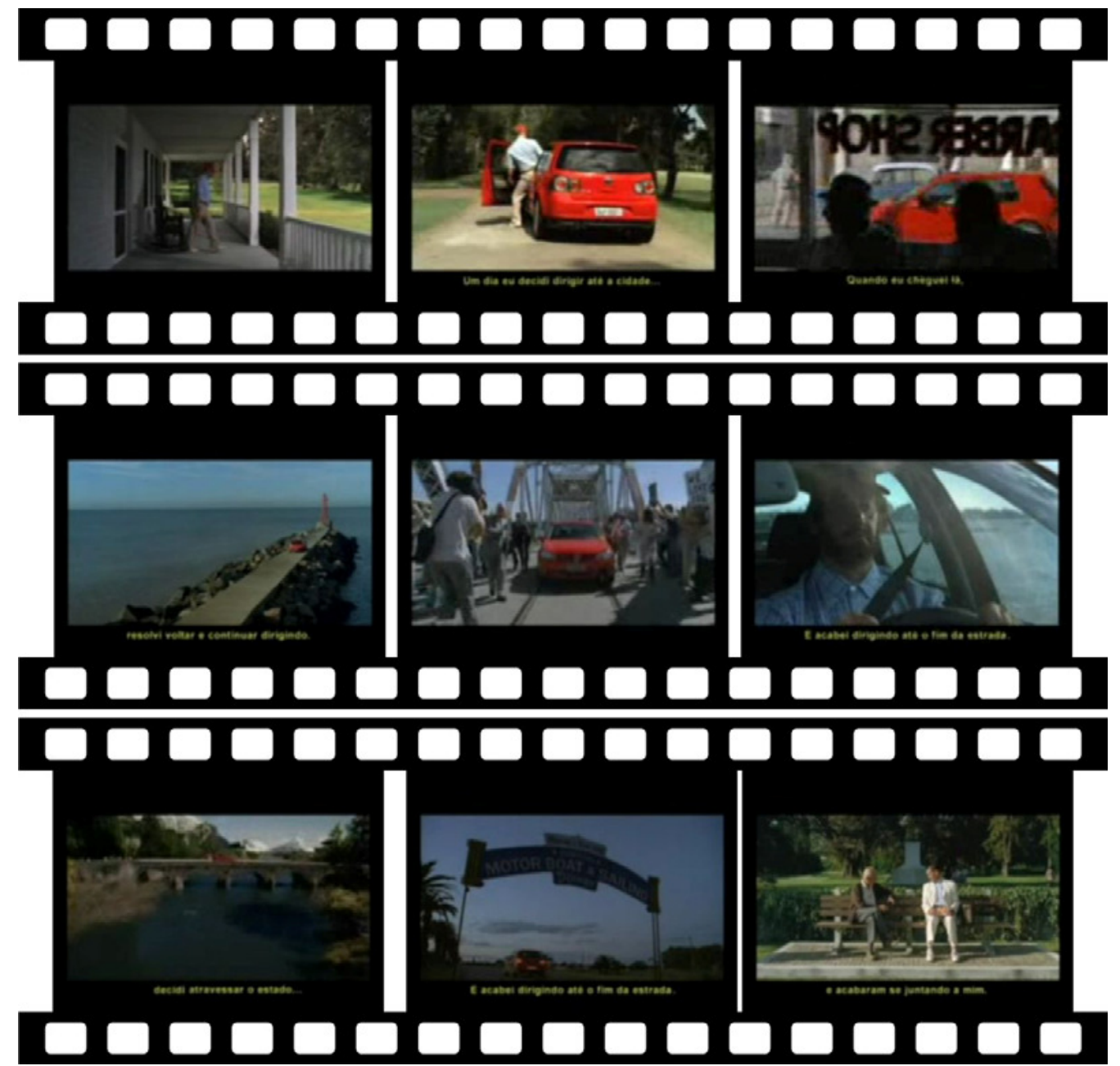

Figura 3 - Spot para o "Golf", paráfrase do filme "Forrest Gump".

Não só as citações diretas a filmes fazem parte da construção audiovisual publicitária. A alusão a filmes também é muito forte, como na campanha criada para as camisas US Top, onde o personagem "Fernandinho" aparecia à mesa de reunião, junto com 
várias outras pessoas e o chefe, como era tratado no filme, dizia com um sotaque italiano: “Que camisa é essa, seu Fernando?”. A peça, da década de 1970, referenciava-se ao filme "O Poderoso Chefão", que foi sucesso na mesma época.

No ano 2000, o filme publicitário "Iguana” (figura 4) para o Fiat Idea Adventure, criado pela agência Leo Burnett Brasil, também se utiliza da alusão a um filme, não falando diretamente sobre ele. O spot trata da relação de amizade entre uma criança e um filhote de iguana que havia sido jogado no esgoto por outra criança. Anos mais tarde, o pequeno animal se transforma em um gigantesco monstro que ataca a cidade. O menino, agora um jovem, chega e comove o monstro, que se lembra do seu passado.

A referência para esta peça publicitária passa por diversos filmes, porém, com maior destaque, devido ao tipo de abordagem de aventura, ao filme "Godzilla".

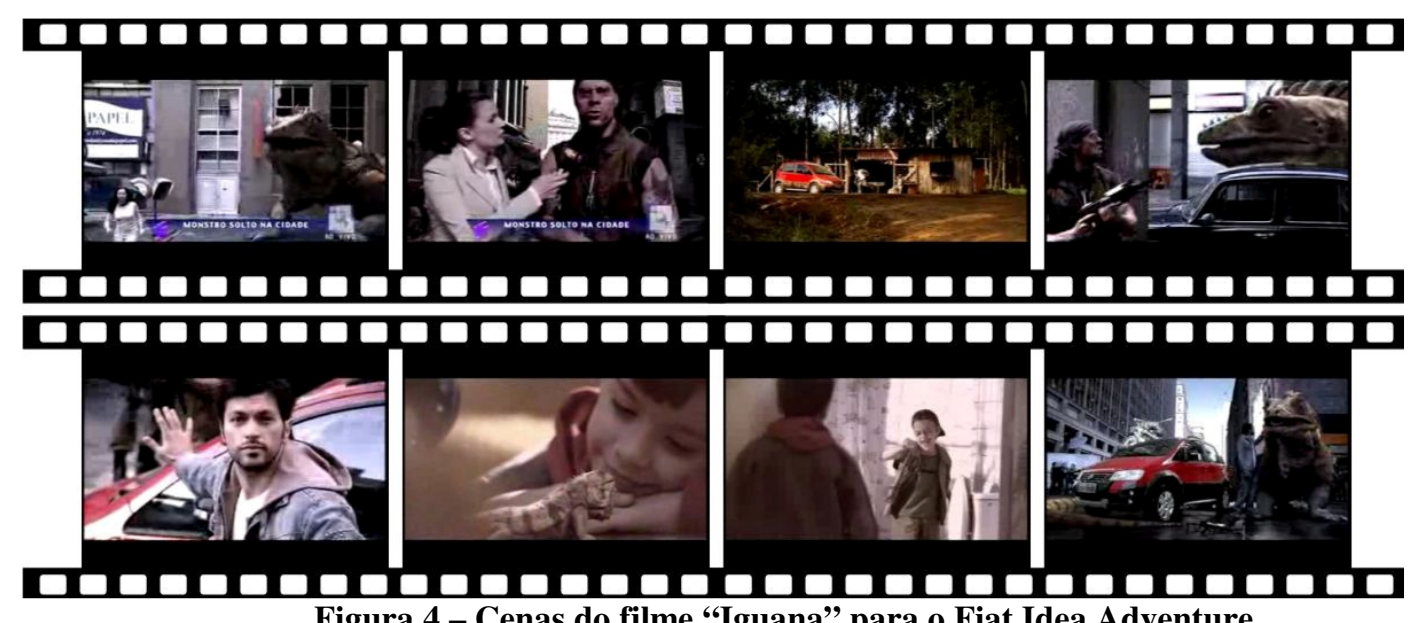

Outro exemplo, desta vez sem fazer a referência a um filme específico, mas, sim, a um gênero fílmico, no caso os filmes de ação, é o spot de lançamento do automóvel "Gol 2009” (figura 5). O enredo do filme mostra o carro passando por perseguições de um helicóptero e vários veículos de combate, desviando-se de mísseis e de explosões. No final, aparece o ator "Silveter Stalone", ícone deste gênero de filmes. 


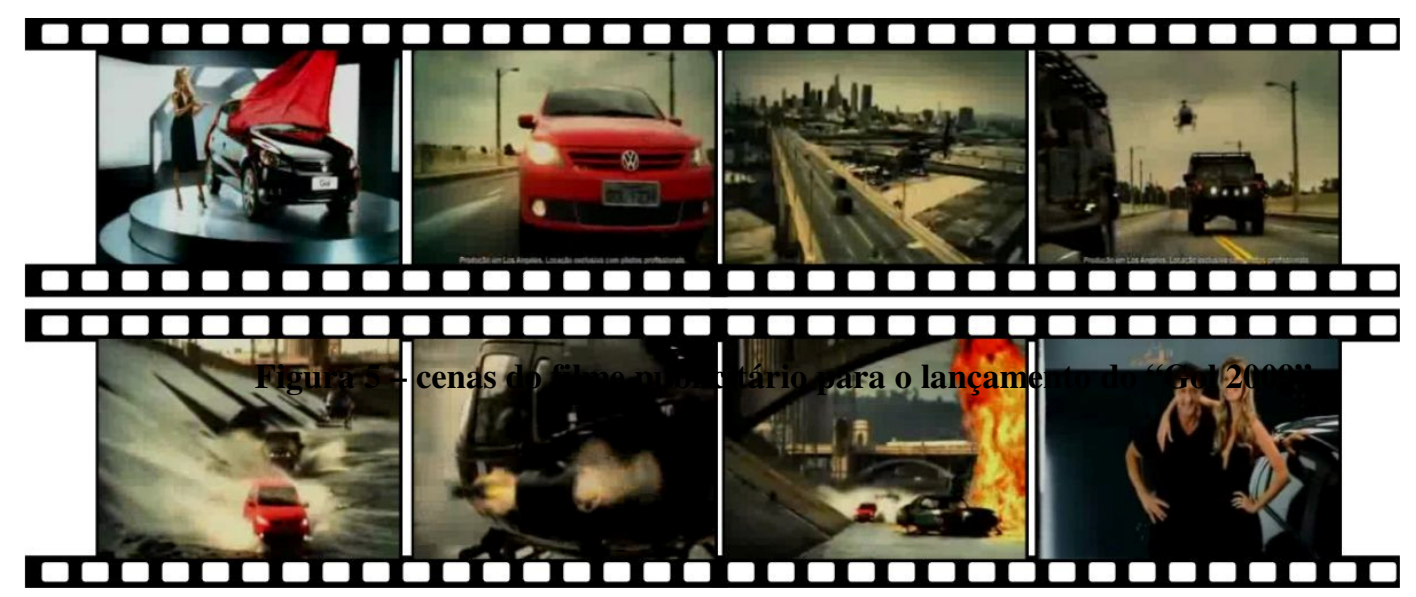

\section{Intertextualidade entre o cinema e a publicidade, o caminho inverso}

O diálogo entre o cinema e a televisão não se dá apenas na relação da publicidade se instrumentalizando a partir do cinema. O cinema também constrói seu repertório a partir da publicidade.

Podemos ver esse diálogo no filme "Boccaccio 70”, produzido em 1962 por Carlo Ponti. O seu segundo episódio, chamado “As tentações do Dr. Antônio” (figura 6), dirigido por Federico Fellini, é sobre a obsessão de um homem por uma peça publicitária.

A história se passa em Roma. Seu protagonista, o personagem Dr. Antonio Mazzuolo, é um homem de meia-idade, que vê o mal em tudo. À noite, costuma sair para flagrar casais de namorados aos beijos em seus carros. Quando instalam próximo à sua casa um gigantesco outdoor, apresentando uma bela e sensual atriz para uma campanha sobre leite, ele o acha altamente ofensivo à moral e faz de tudo para que o mesmo seja removido. Da janela de sua casa, entretanto, não se cansa de olhar para o cartaz através de um binóculo.

Ele se torna tão obsessivo em relação ao outdoor que, certo dia, ao passar pelo local, ouve uma voz chamando-o e vê aquela imensa figura ganhar vida e vir em sua direção. Sua obsessão torna-se cada vez mais séria até que bombeiros e uma ambulância são chamados para retirá-lo do alto do imenso outdoor. 


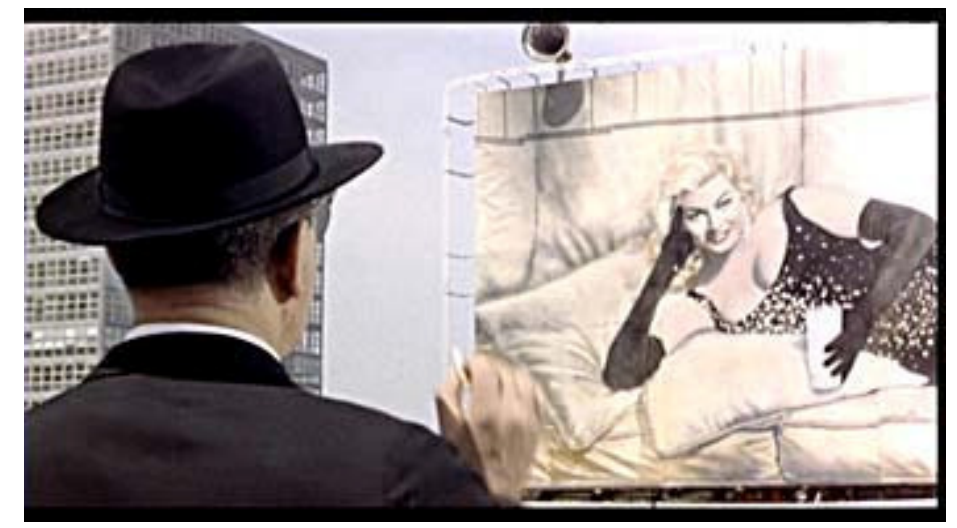

figura 6 - Dr. Antônio frente ao outdoor, objeto de sua obsessão.

Outro filme em que a publicidade aparece de uma forma crítica é "O SHOW DE TRUMAN - O Show da Vida", dirigido por Peter Weir em 1998. O filme conta a história de Truman, que vive, desde seu nascimento, em um mundo real paralelo, criado por uma emissora de TV. Uma cidade em que todos os moradores são atores, e toda ela é um grande cenário para enganar Truman e fazê-lo viver uma vida real televisionada.

No filme, o programa "O Show de Truman" se torna o show mundial de maior sucesso e confunde a cabeça do público sobre o que é realidade, pois tudo não passa de "fake". O mundo criado para Truman é totalmente manipulável, assim como sua vida, fazendo com que o diretor do programa se torne "o Deus" daquela cidade, que possui grande apelo publicitário mesmo sem possuir intervalos comerciais. São cartazes, produtos usados pelos "moradores" e outdoors espalhados por toda a programação. Inclusive muito do que aparece na produção é vendido no mundo real. Sua mulher faz comerciais disfarçados na hora da refeição, como a recorrente imagem do six-pack de cerveja virado para a câmara ou uma pose exageradamente persuasiva.
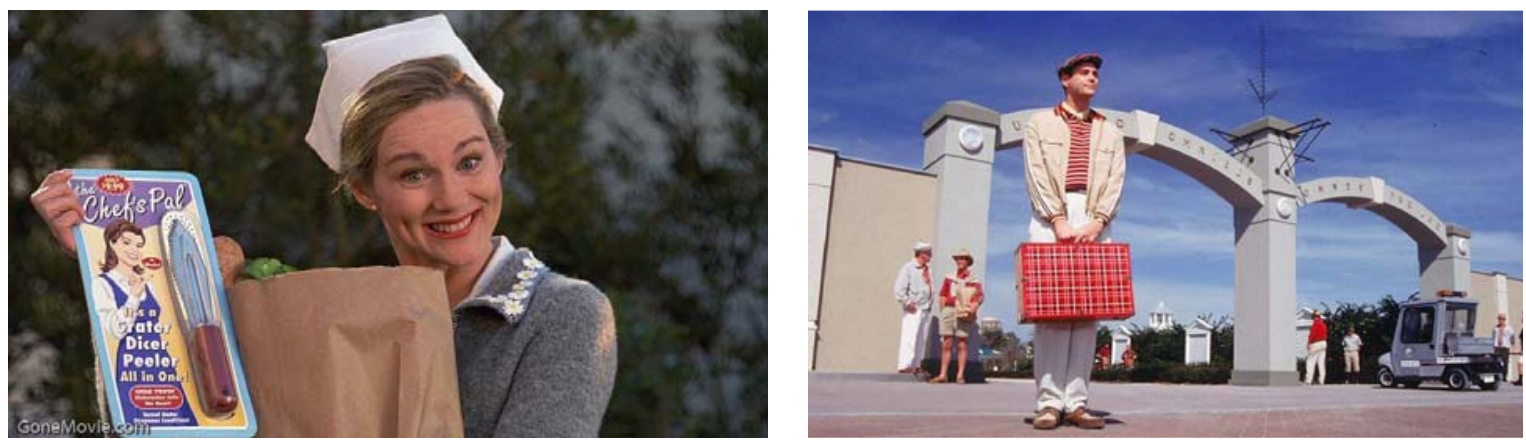

Figura 7 - "O show de Truman". 
São muitos os exemplos dessa relação intertextual, dentre os quais não podemos deixar de citar filmes como:

“Crazy people - Muito Loucos”, (Crazy People), de 1990, dirigido por Tony Bill. A história de um publicitário que atravessa um momento delicado por ter sido abandonado pela esposa. Ele repentinamente tem crises de honestidade e cria uma campanha publicitária que é calcada em dizer só a verdade sobre cada produto. Seu chefe o obriga a se internar para ter tratamento psiquiátrico, mas o material da campanha equivocadamente é impresso e se torna um enorme sucesso. Internado, elabora novas campanhas, ajudado pelos outros internos.

"Do que as mulheres gostam", (What Women Want) de 2000, narra a vida de Nick Marshall, um publicitário machista que trabalha numa das maiores agências de propaganda de Chicago e sua carreira é ameaçada quando a agência contrata Darcy McGuire como a nova diretora de criação, cargo que ele julgava ser seu. Após tomar um choque na banheira, passa a escutar a mente das mulheres e começa a usar esse novo "dom" ao seu favor. Podemos destacar a cena em que ele recebe uma caixa rosa cheia de produtos femininos, com a tarefa de experimentá-los para criar campanhas.

“Adeus, Lênin!” de 2003. Em 1989, uma mulher entra em coma na Alemanha Oriental e fica desacordada durante os dias que marcaram o triunfo do regime capitalista. Quando ela desperta, em 1990, Berlim Oriental está modificada. Seu filho, temendo que a excitação causada pelas drásticas mudanças possa lhe prejudicar a saúde, decide esconder-lhe os acontecimentos. Chega a produzir programas de televisão para evitar que ela tome contato com a nova realidade capitalista e reproduzir uma marca de pepinos em conserva, que só eram produzidos durante regime socialista. A visão de um painel publicitário da Coca-Cola faz com que ela tome consciência da nova realidade.

“Encontros e Desencontros,” também de 2003, onde um ator fracassado, e que agora só consegue trabalhos em filmes publicitários, vai a Tóquio gravar um comercial e encontra a esposa de um fotógrafo, quando os dois passam juntos por uma viagem de autoconhecimento.

O filme francês "99 Francos", produzido em 2007 e dirigido por Jan Kounen, conta a história de Octave, redator na maior agência do mundo, a fictícia Ross and Witchcraft. O filme é uma dura crítica à propaganda e à profissão e conta como uma idéia "genial" pode se tornar um filme "medíocre" após o cliente impor sua própria versão. 
Também as produções nacionais "E se eu fosse você", de 2006 e "E se eu fosse você 2”, de 2008, falam sobre um publicitário bem sucedido que por um fenômeno inexplicável, troca de corpo com a sua esposa, uma professora de um coral infantil.

Além dos filmes de longa-metragem, estão o seriado para a televisão "A Feiticeira", produzido entre 1964 a 1972, que mostrava a relação de um casal formado por um publicitário e uma bruxa, e a série "Mad Men", do canal HBO, de 2007, que mostra o mundo da publicidade dos anos 1960, em especial, as agências de publicidade instaladas na Madison Avenue de Nova York.

\section{Considerações finais}

\section{O cinema, a publicidade e a estética do consumo}

As imagens publicitárias, nesse diálogo com a cultura de sua época, se inserem em complexas tramas discursivas, onde passado, presente e futuro se mobilizam na produção de significações.

Como se vê, a linguagem publicitária se expressa em uma narrativa cheia de alusões ao repertório cultural do receptor, atendendo ao seu saber enciclopédico e a sua memória coletiva, para comunicar-se de modo mais eficiente - misturando o antigo e o moderno, a arte contemporânea e a clássica, a música erudita e o rap, com textos que parecem terem sido retirados de um poema, de uma voz do cotidiano ou de um roteiro cinematográfico, mediante a emulação do discurso coloquial. Tudo lembra alguma coisa que já vimos ou ouvimos, mas que parece novo e original além de muito importante e criativo.

Durante todo o trajeto da história do cinema e do filme publicitário, que também é um trajeto de construção de uma linguagem própria, a relação com as manifestações artísticas que foram surgindo e o aparecimento de novas tecnologias de comunicação, provocaram, segundo Júlio Plaza, um "deslocamento das funções instauradoras (a poética do artista) para funções da sensibilidade receptora (estética), o que produz no meio artístico uma grande confusão conceitual, caracterizada pela mistura e hibridação de gêneros, poéticas e atitudes artísticas" (2000 p.76).

Uma obra de ficção, seja um filme ou publicidade, permite uma série de experiências sensoriais ao espectador, através de imagens míticas geradas pela mídia. 
O consumidor contemporâneo se relaciona ao que é exposto, de uma forma diferente da que acontecia nos primórdios do cinema e da televisão.

Gilles Lipovetsky, lembra que "nenhum anúncio publicitário, por mais sedutor que seja, convencerá os consumidores pós-modernos a abdicarem da liberdade de escolha que arduamente conquistaram" (1989, p.13).

Quando o cinema chega à televisão, traz consigo padrões estéticos que são incorporados ao meio e utilizados pela publicidade.

Em muitos casos, a publicidade contemporânea, produzida com a tecnologia e a linguagem adaptadas do cinema, tornou-se mais atraente do que a própria programação.

Segundo o crítico de cinema Ismail Xavier, "o cinema não fornece apenas uma imagem (aparência) do real, mas é capaz de constituir um mundo a imagem do real". (1984.p.86). A estética cinematográfica contribui para a formação e a evolução do comportamento da sociedade, ávida por novos mitos a cultuar e por novos sonhos de consumo.

\section{Referências bibliográficas}

APPADURAI, A. Disjunção e diferença na economia cultural global. In: FEATHERSTONE, M. (org.) Cultura global: nacionalismo, globalização e modernidade. Petrópolis: Vozes, 1999.

AUMONT, Jacques (et al.). A estética do filme. Campinas: Papirus, 1993.

BAKHTIN, M (Volochinov). Marxismo e filosofia da linguagem. São Paulo: Hucitec, 1997.

BAKHTIN, Mikhail. Problemas da poética de Dostoiévski. $3^{\text {a }}$ ed., Rio de Janeiro: Forense Universitária, 2005.

Hucitec, 1988.

Questões de literatura e estética: a teoria do romance. São Paulo:

BAUMAN, Z. Modernidade líquida. Rio de Janeiro: Zahar, 2001.

BENJAMIN, Walter. A obra de arte na era de sua reprodutibilidade técnica. in: Obras escolhidas. 6. edição. São Paulo: Editora Brasiliense, 1993. v. 01.

BOURDIEU, P. A economia das trocas simbólicas. São Paulo: Perspectiva, 2001.

CARRASCOZA, João Anzanello. Do caos à criação publicitária: processo criativo, plágio e readymade na publicidade. São Paulo: Saraiva, 2008.

DELEUZE, Gilles. O ato de criação. Folha de São Paulo. São Paulo: 27 jun 1999. 
LIPOVETSKY, G. O império do efêmero: a moda e seu destino nas sociedades modernas. São Paulo: Cia. das Letras, 1989.

KRISTEVA, J. Introdução à Semanálise. São Paulo: Perspectiva, 1974.

KULECHOV, León. Tratado de la realización cinematográfica. Buenos Aires: Futuro, 1947

McLUHAN, Marshall. Os meios de comunicação como extensão do homem. São Paulo: Cultrix, 1974.

METZ, Critian. Linguagem e cinema. Trad. Marilda Pereira. São Paulo: Perspectiva, 1980.

PLAZA, Julio. Arte e Interatividade: autor-obra-recepção. in: Revista de Pós-graduação, CPG, Instituto de Artes, Unicamp, 2000.

QUESSADA, D. O poder da publicidade na sociedade consumida pelas marcas. São Paulo: Futura, 2003.

RAMONET, Ignácio. Propagandas silenciosas: massas, televisão, cinema. Petrópolis/RJ: Vozes, 2002.

RODRIGUES, A. D. Tendências actuais da publicidade . In: Revista de Comunicação e Linguagens. N.5 (1987). Porto: Afrontamento, 1987.

ROSSI-LANDI, F. A linguagem como trabalho e como mercado: uma teoria da produção e da alienação linguísticas. São Paulo: Difel, 1985.

SANTOS, Goiamérico Felício C. dos. Publicidade e propaganda: o entrelugar dos discursos. In: GOMES, Neusa. Fronteiras da publicidade: faces e disfarces da linguagem persuasiva. Porto Alegre: Sulina, 2006.

SARLO, B. Cenas da vida pós-moderna. Rio de Janeiro: UFRJ, 2004.

XAVIER, Ismail. O Discurso Cinematográfico: a opacidade e a transparência. São Paulo: Paz e Terra, 1984. 